\title{
Article \\ Effects of Aspen and Spruce Density on Size and Number of Lower Branches 20 Years after Thinning of Two Boreal Mixedwood Stands
}

\author{
Philip G. Comeau (1)
}

check for updates

Citation: Comeau, P.G. Effects of Aspen and Spruce Density on Size and Number of Lower Branches 20 Years after Thinning of Two Boreal Mixedwood Stands. Forests 2021, 12, 211. https://doi.org/10.3390/ 12020211

Academic Editors: Timothy A. Martin and Ignacio Barbeito

Received: 29 December 2020

Accepted: 8 February 2021

Published: 11 February 2021

Publisher's Note: MDPI stays neutral with regard to jurisdictional claims in published maps and institutional affiliations.

Copyright: (C) 2021 by the author. Licensee MDPI, Basel, Switzerland. This article is an open access article distributed under the terms and conditions of the Creative Commons Attribution (CC BY) license (https:// creativecommons.org/licenses/by/ $4.0 /)$.
Department of Renewable Resources, University of Alberta, Edmonton, AB T6G 2H1, Canada; phil.comeau@ualberta.ca

\begin{abstract}
This study examined branch diameter, number of whorls, and number of branches in the lower $2 \mathrm{~m}$ of the stems of white spruce growing in pure stands and in mixture with a range of densities of trembling aspen. Data were collected from two study sites located north of Big River Saskatchewan, which were regenerated following clearcutting in 1992 and thinned in 1996 to five aspen densities and two spruce densities. Results show significant decreases in spruce diameter at breast height $(\mathrm{DBH})$, height, live crown ratio, maximum branch diameter in the lower $2 \mathrm{~m}$, average branch diameter in the whorl closest to $1 \mathrm{~m}$, and increases in tree slenderness with increases in aspen density. Increasing spruce density reduced the number of live branches and number of live branch whorls in the lower $2 \mathrm{~m}$. Maximum branch diameter in the whorl closest to $1 \mathrm{~m}$ was influenced by both aspen and spruce density, with a significant interaction term resulting from effects of intraspecific competition being evident for aspen densities of 1500 stems ha $^{-1}$ or lower. DBH and slenderness explained more than $49 \%$ of the variation in spruce crown width, maximum branch diameter in the lower $2 \mathrm{~m}$, maximum live branch diameter in the whorl closest to $1 \mathrm{~m}$, and average live branch diameter in the whorl closest to $1 \mathrm{~m}$. DBH explained more variation in crown width and branch diameter than slenderness. This study demonstrates that growing spruce in mixture with aspen can lead to reductions in branch size and that early thinning to low aspen densities could lead to increases in size of knots and associated reductions in wood quality, particularly when spruce densities are low.
\end{abstract}

Keywords: white spruce; pre-commercial thinning; crown size; branch diameter; branch number; knots; wood quality

\section{Introduction}

Knot size and number influence the strength, appearance, and value of sawn lumber $[1,2]$. Knots result when the tree stem grows around branches and may be continuous from pith to bark in the case of living non-epicormic branches or may terminate within the stem, beneath the bark, after branch death.

As well as leading to reductions in growth rates [3], increases in intra- and interspecific competition (associated with a decrease in spacing or an increase in density) result in reductions in both branch size $[1,4-8]$ and branch number $[9,10]$ in the lower portion of a spruce stem, leading to both smaller and fewer knots. Slenderness, crown radius, live crown ratio, and other individual tree characteristics are also influenced by the social status of a tree and by both intra- and inter-specific competition [1]. Neighboring competitors may cause crown rise due to the shading of lower branches, which leads to an increase in height to the crown base and reductions in both crown length and live crown ratio [11-14]. Effects of competition on height to crown base, crown length, and crown ratio also depend on species shade tolerance, with tolerant species having longer crowns and lower height to crown base than intolerant species [15]. Consequently, it may be desirable to retain moderate to high densities of intolerant deciduous competitors in young stands to control 
knot size in moderately shade-tolerant spruce, even though the fastest growth of white spruce is achieved at very low aspen densities $[16,17]$.

Several studies indicate that branch diameter, height to base of live crown, and the number and size of knots are related to crown radius [1,14,18,19], slenderness (ratio of height to DBH) $[1,6,9,20]$, and tree size (DBH and/or height) $[2,7,14]$. In addition, while the height where maximum branch diameters occur on the stem varies with stand and tree characteristics, it is typically located between $25 \%$ and $75 \%$ of the height of the tree and occurs near the mid-crown in stands with moderate density $[5,7,21,22]$. Upward shifts in the location of maximum branch diameters are associated with increases in stand density and related increases in tree slenderness [2,7].

Mixtures of trembling aspen (Populus tremuloides Michx.) and white spruce (Picea glauca (Moench) Voss) are a common natural stand type on upland sites in the western boreal forests of Canada, and spruce wood quality may be higher when it is grown together with aspen [23]. However, there is little information currently available to guide the application of thinning treatments in terms of effects of aspen and spruce densities on white spruce crown characteristics associated with wood quality. In this paper, I examine effects of a wide range of aspen densities and a narrow range of spruce densities on branch diameters and numbers in two 26-year-old plantations located in western Saskatchewan. Hypotheses being tested are (1) crown size and the number and diameter of branches on the lower bole of young spruce will decrease with increasing aspen and spruce densities and increase following thinning treatments, and (2) spruce crown size and branch diameter will increase with increasing diameter at breast height (DBH) and decrease with increasing slenderness.

\section{Materials and Methods}

The Western Boreal Growth and Yield Association (WESBOGY) Long-Term Study was initiated in 1990 to advance knowledge of the dynamics of mixedwood stands in response to an identified need for information on the effects of aspen density on spruce and aspen growth [16]. The study involved planting white spruce seedlings in recently clearcut areas where aspen regeneration had already established. Spruce and aspen were thinned to desired treatment densities at age 5 . The Long-Term Study currently includes a total of 615 plots with 20 installations (Figure 1) established and maintained by 11 agencies in Alberta, British Columbia, Manitoba, Saskatchewan, and the Northwest Territories. Each installation consists of two replications of 15 treatments (Table 1). Measurement plots are $20 \mathrm{~m} \times 20 \mathrm{~m}(0.04 \mathrm{ha})$ with a 5- to 10 - meter-wide treated buffer on each side of the measurement plot.

Table 1. Spruce and aspen treatment densities established in each replicate in the WESBOGY LongTerm Study (i.e., one replicate of each of the 15 treatments was established in each replicate). For the study presented in this paper, white spruce were measured in the Big River installations in the 10 treatments shown in bold out of the 15 treatments that had been established for the study.

\begin{tabular}{ccccccc}
\hline & \multicolumn{7}{c}{ Trembling Aspen (Aw) Density (Stems ha ${ }^{-1}$ ) } \\
\hline White Spruce (Sw) Density (Stems ha ${ }^{-1}$ ) & $\mathbf{0}$ & $\mathbf{2 0 0}$ & $\mathbf{5 0 0}$ & $\mathbf{1 5 0 0}$ & $\mathbf{4 0 0 0}$ & Natural \\
\hline $\mathbf{1 0 0 0}$ & $\mathbf{1}$ & 2 & $\mathbf{3}$ & $\mathbf{4}$ & $\mathbf{5}$ & $\mathbf{6}$ \\
$\mathbf{5 0 0}$ & 7 & 8 & $\mathbf{9}$ & $\mathbf{1 0}$ & $\mathbf{1 1}$ & $\mathbf{1 2}$ \\
$\mathbf{0}$ & $\mathrm{X}$ & $\mathrm{X}$ & $\mathrm{X}$ & 13 & 14 & 15 \\
\hline
\end{tabular}

NOTES: 1. Treatment numbers (1-15). 2. Empty cells $(X)$ for treatments not established.

In this paper, the effects of treatments on branch number and size on the lower $2 \mathrm{~m}$ of spruce stems are examined using measurements collected at age 26 in the two Big River, Saskatchewan installations. These installations were established by Weyerhaeuser Canada in 1992 approximately $30 \mathrm{~km}$ north of the town of Big River, Saskatchewan. The Median $\left(54.09^{\circ} \mathrm{N} 107.07^{\circ} \mathrm{W}\right.$, elev $\left.=515 \mathrm{~m}\right)$ and Superior $\left(54.05^{\circ} \mathrm{N} 106.98^{\circ} \mathrm{W}\right.$, elev $\left.=505 \mathrm{~m}\right)$ installations were harvested in June of 1992, with aspen allowed to regenerate naturally by root suckering and with spruce planted in September of 1992. Thinning treatments were 
completed in September of 1996. Both installations were level, moderately well drained, had Gray Luvisolic soils [24] and mesic to subhygric soil moisture regimes.

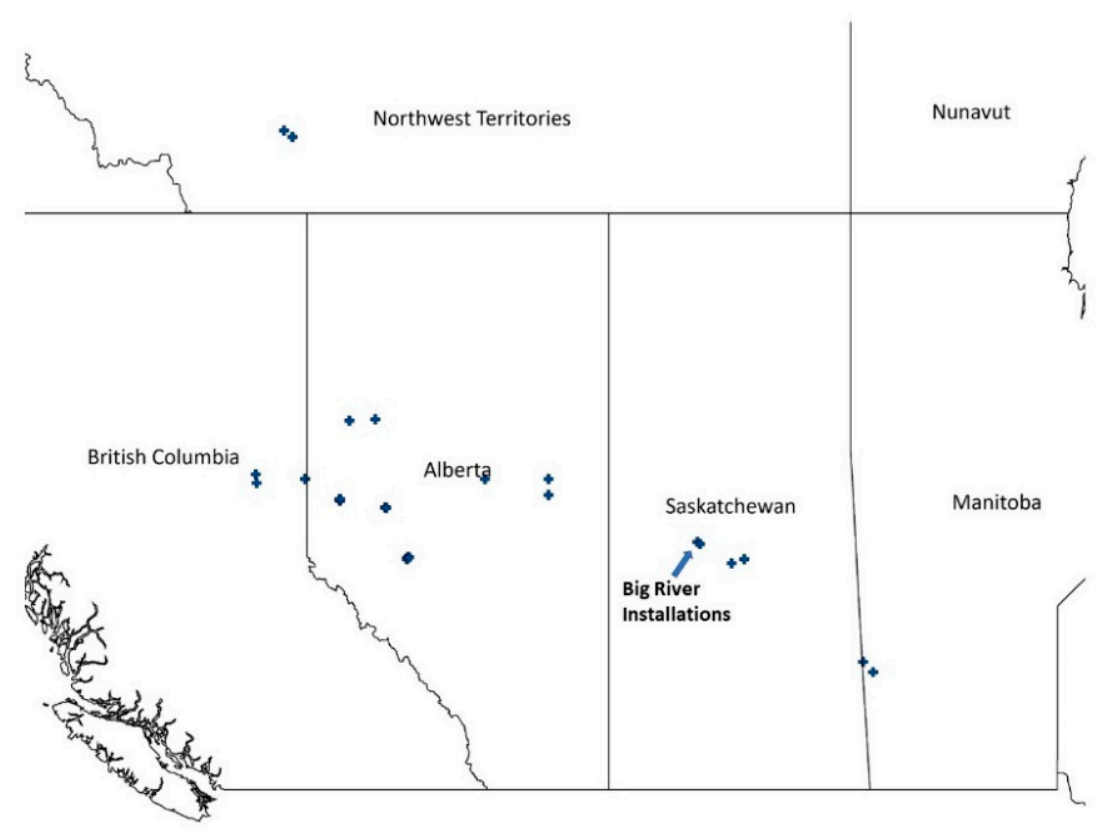

Figure 1. Locations of the 20 Western Boreal Growth and Yield Association (WESBOGY) Long-Term Study Installations and the two Big River installations used for this study in western Canada.

For this study, the number and size of knots on the lower portion of the stem was measured for two top height spruce (one in the SW quarter and one in the NE quarter of the $20 \mathrm{~m} \times 20 \mathrm{~m}$ plots) in ten selected treatment plots in each replicate [Table 1; treatments 1 (1000 white spruce (Sw) and 0 trembling aspen (Aw)), 3 (1000 Sw and $500 \mathrm{Aw}), 4(1000 \mathrm{Sw}$ and $1500 \mathrm{Aw}$ ), 5 (1000 Sw and $4000 \mathrm{Aw}), 6$ (1000 Sw and natural Aw density), 7 (500 Sw and $0 \mathrm{Aw}), 9$ (500 Sw and $500 \mathrm{Aw}), 10$ (500 Sw and $1500 \mathrm{Aw}), 11$ (500 Sw and $4000 \mathrm{Aw}$ ), and 12 (500 Sw and natural Aw density)]. Top height spruce was defined as the largest diameter white spruce in each selected plot that was free of major stem deformities. Measurement involved (a) for all whorls below $2 \mathrm{~m}$ height, diameter of largest diameter branch on each whorl, and a count number of live and dead branches on each whorl; and (b) for the first whorl above $1 \mathrm{~m}$ height, diameter of every branch. In addition, diameter at breast height (DBH, measured at $1.30 \mathrm{~m}$ above the ground), height, height to crown base, and crown width were measured for the selected spruce. Crown base was defined as the lowest point on the bole with a relatively complete whorl of live branches. Crown length was calculated as the difference between tree height and height to crown base, and live crown ratio was calculated by dividing crown length by tree height. Crown radius was measured on the north and on the west sides of the selected spruce, for the height where the crown was widest and crown width was calculated as the sum of the two crown radius measurements. Slenderness of each sampled tree was calculated by dividing tree height by $\mathrm{DBH}$.

Measurement of the Median installation was completed during August 2018 and measurement of the Superior installation was completed during May 2019.

Mixed models were used to examine the effects of prescribed aspen and spruce density on branch diameters, numbers of branches, and number of whorls for this randomized complete block design, using SAS9.4 proc Mixed (SAS Institute, Cary, NC, USA). Installation, replicate, and tree were included as nested random effects in the mixed model analysis of variance. Post hoc comparisons used Tukey's HSD to test for differences between treatments when ANOVA indicated significant treatment effects.

Linear regression was used to examine the use of current tree and stand characteristics in describing variation in crown and branch size. Preliminary correlation analysis indicated 
intercorrelations between all potential independent variables; consequently, models were constructed using only individual variables. Random effects were tested initially in these linear models, but since they were not significant $(p>0.05)$, simple linear regression (completed using proc Reg) was used. The simple linear regression models tested in this study were of the form:

$$
\mathrm{Y}=\mathrm{a}+\mathrm{bX}+\mathrm{e}
$$

where $\mathrm{Y}$ was the dependent variable (e.g., live crown ratio), a $\left(\beta_{0}\right)$ was the intercept term, $\mathrm{b}\left(\beta_{1}\right)$ was the slope, $X$ was the independent variable (e.g., tree height), and e was error.

\section{Results}

\subsection{Thinning Effects on Stand and Crown Characteristics}

While the ranking of treatments in terms of stand densities at age 26 is consistent with the ranking of treatments by target densities, treatment densities have declined below target densities over the 21-year period following thinning (Table 2). Aspen densities measured in these plots have declined substantially in the unthinned plots from initial values of between 40,000 and 200,000 stems ha ${ }^{-1}$ in year 1 to 2639 stems ha $^{-1}$ in year 26 . Aspen basal area in the unthinned treatment did not differ significantly from basal area in the 4000 or 1500 stems ha ${ }^{-1}$ treatments. Spruce basal area in the treatments with 500 stems ha $^{-1}$ of spruce was about $40 \%$ of that found in the 1000 stems ha $^{-1}$ treatments at age 26 .

Table 2. Effects of thinning treatments applied at age 5 on stand densities (SPH, expressed in terms of stems ha ${ }^{-1}$ ) and stand basal area (expressed as $\mathrm{m}^{2} \mathrm{ha}^{-1}$ ) of the two primary species at age 26. For aspen (Aw) treatment density (AwTDen) and spruce (Sw) treatment density (SwTDen) means followed by different letters were found to differ significantly $(\alpha=0.05)$ based on Tukey's HSD test.

\begin{tabular}{|c|c|c|c|c|c|c|}
\hline \multirow{2}{*}{$\begin{array}{c}\text { Aw Treatment } \\
\text { Density } \\
\left(\text { Stems ha }^{-1}\right)\end{array}$} & \multirow{2}{*}{$\begin{array}{c}\text { Sw Treatment } \\
\text { Density } \\
\left(\text { Stems ha }^{-1}\right)\end{array}$} & \multirow[t]{2}{*}{$\begin{array}{c}\text { Aw SPH } \\
\left(\text { Stems ha }{ }^{-1}\right)\end{array}$} & \multirow{2}{*}{$\begin{array}{c}\text { Aw Basal } \\
\text { Area } \\
\left(\mathrm{m}^{2} \mathrm{ha}^{-1}\right)\end{array}$} & \multirow[t]{2}{*}{$\begin{array}{c}\text { Sw SPH } \\
\left(\text { Stems ha }^{-1}\right)\end{array}$} & \multicolumn{2}{|c|}{ Sw Basal Area/ha $\left(\mathrm{m}^{2} \mathrm{ha}^{-1}\right)$} \\
\hline & & & & & SwTDen $=500$ & SwTDen $=1000$ \\
\hline 0 & & & & & $4.7 \mathrm{a}$ & $11.4 \mathrm{ab}$ \\
\hline 200 & & $159.5 c$ & $5.5 c$ & & 3.3ab & $12.6 \mathrm{a}$ \\
\hline 500 & & $386.0 \mathrm{bc}$ & $9.8 \mathrm{c}$ & & $3.5 a$ & $4.9 \mathrm{abc}$ \\
\hline 1500 & & $1067.2 b$ & $15.7 \mathrm{~b}$ & & $1.5 \mathrm{bc}$ & $5.1 \mathrm{abc}$ \\
\hline 4000 & & $1978.8 \mathrm{a}$ & $21.2 \mathrm{a}$ & & $1.3 \mathrm{c}$ & $2.0 \mathrm{bc}$ \\
\hline \multirow[t]{3}{*}{ Unthinned } & & $2638.7 \mathrm{a}$ & $19.4 \mathrm{ab}$ & & $0.4 \mathrm{c}$ & $1.6 \mathrm{c}$ \\
\hline & 500 & & & $306.4 \mathrm{~b}$ & \multicolumn{2}{|c|}{$2.5 b$} \\
\hline & 1000 & & & $709.1 \mathrm{a}$ & \multicolumn{2}{|c|}{$6.2 \mathrm{a}$} \\
\hline$p$ AwTDen & & $<0.0001$ & $<0.0001$ & $\mathrm{~ns}$ & $<0.0001$ & $<0.0081$ \\
\hline p SwTDen & & ns & ns & 0.0031 & \multicolumn{2}{|c|}{$<0.0001$} \\
\hline
\end{tabular}

Effects of spruce density on spruce height, DBH, slenderness, crown width, and live crown ratio were not significant (results not shown). Table 3 shows the effects of aspen treatment density based on measurements from the two top height spruce sampled in each plot. Height, DBH, crown width, and live crown ratio were smaller in the unthinned than in other treatments. DBH and crown width were larger in the 0 and 500 aspen ha ${ }^{-1}$ treatments than in the unthinned, and live crown ratio was slightly but significantly smaller in the unthinned treatment compared to all other treatments. Both height and slenderness were largest for the 4000 aspen $\mathrm{ha}^{-1}$ treatment, which may result from ideal conditions for height growth coupled with some suppression of spruce diameter growth after the aspen canopy closed in this treatment at about age 15 . 
Table 3. Effects of aspen thinning (Aw treatment density) on height, diameter at breast height (DBH), slenderness, crown width, and live crown ratio for the trees sampled in each treatment. Within each column, means followed by different letters were found to differ significantly $(\alpha=0.05)$ based on Tukey's HSD test. $(\alpha=0.05)$.

\begin{tabular}{cccccc}
\hline $\begin{array}{c}\text { Aw Treatment } \\
\text { Density } \\
(\text { Stems ha }\end{array}$ & $\begin{array}{c}\text { Height } \\
(\mathbf{m})\end{array}$ & $\begin{array}{c}\text { DBH } \\
(\mathbf{c m})\end{array}$ & Slenderness & $\begin{array}{c}\text { Crown Width } \\
(\mathbf{m})\end{array}$ & $\begin{array}{c}\text { Live Crown } \\
\text { Ratio }\end{array}$ \\
\hline 0 & $8.04 \mathrm{ab}$ & $17.30 \mathrm{a}$ & $0.471 \mathrm{~b}$ & $3.92 \mathrm{a}$ & $0.891 \mathrm{a}$ \\
500 & $8.10 \mathrm{ab}$ & $12.91 \mathrm{abc}$ & $0.670 \mathrm{ab}$ & $3.56 \mathrm{a}$ & $0.885 \mathrm{a}$ \\
1500 & $8.05 \mathrm{ab}$ & $11.53 \mathrm{bcd}$ & $0.708 \mathrm{ab}$ & $3.28 \mathrm{ab}$ & $0.889 \mathrm{a}$ \\
4000 & $8.98 \mathrm{a}$ & $8.10 \mathrm{~cd}$ & $1.169 \mathrm{a}$ & $2.60 \mathrm{bc}$ & $0.879 \mathrm{a}$ \\
Unthinned & $5.40 \mathrm{~b}$ & $6.90 \mathrm{~d}$ & $0.793 \mathrm{ab}$ & $2.23 \mathrm{c}$ & $0.818 \mathrm{~b}$ \\
$p$ & 0.0489 & $<0.0001$ & 0.0435 & 0.0001 & 0.0313 \\
\hline
\end{tabular}

\subsection{Treatment Effects on Number and Diameter of Branches}

Maximum live branch diameter in the lower $2 \mathrm{~m}$ of the spruce stems differed significantly between aspen treatment densities with $0>(500,1500)>(4000$, unthinned) (Table 4). Although results indicate that the number of live branches and number of live branch whorls below $2 \mathrm{~m}$ height decrease with increasing aspen density, the effect of aspen density was not significant. However, spruce density did have a significant effect on the number of live branches and number of live branch whorls below $2 \mathrm{~m}$ height, with both values being smaller at the higher spruce density.

Table 4. Effects of thinning treatments on maximum branch diameter, number of live branches, and number of live branch whorls in the lower $2 \mathrm{~m}$ of dominant spruce. Analysis for treatment effects was based on a factorial design with three levels for aspen density and two levels for spruce density. For both aspen treatment density (AwTDen) and spruce treatment density (SwTDen), means followed by different letters were found to differ significantly $(\alpha=0.05)$ based on Tukey's HSD test.

\begin{tabular}{|c|c|c|c|c|c|c|}
\hline & \multicolumn{2}{|c|}{$\begin{array}{c}\text { Maximum Branch Diameter } \\
\text { below } 2 \mathrm{~m} \text { Height }\end{array}$} & \multicolumn{2}{|c|}{$\begin{array}{l}\text { Number of Live Branches } \\
\text { below } 2 \mathrm{~m} \text { Height }\end{array}$} & \multicolumn{2}{|c|}{$\begin{array}{c}\text { Number of Live Branch Whorls } \\
\text { below } 2 \mathrm{~m} \text { Height }\end{array}$} \\
\hline & $p$ & Means (cm) & $p$ & Means (cm) & $p$ & Means (cm) \\
\hline AwTDen & $<0.001$ & & ns & & ns & \\
\hline SwTDen & ns & & 0.0052 & & 0.0365 & \\
\hline AwTDen*SwTDen & ns & & ns & & ns & \\
\hline AwTDen = 0 & & $3.46 \mathrm{a}$ & & 21.9 & & 7.6 \\
\hline AwTDen = 500 & & $2.55 b$ & & 20.1 & & 7.5 \\
\hline AwTDen = 1500 & & $2.41 b$ & & 16.5 & & 5.6 \\
\hline AwTDen $=4000$ & & $1.92 \mathrm{c}$ & & 19.9 & & 6.9 \\
\hline AwTDen = unthinned & & $1.68 \mathrm{c}$ & & 18.9 & & 6.5 \\
\hline SwTDen = 500 & & & & $21.9 a$ & & $7.5 \mathrm{a}$ \\
\hline SwTDen $=1000$ & & & & $17.3 b$ & & $6.2 b$ \\
\hline
\end{tabular}

Measurements taken at the whorl closest to $1 \mathrm{~m}$ show significant effects of aspen density on average branch diameter and significant effects of spruce density on number of live branches (Table 5). Branch diameter declined with increasing aspen density, and the number of live branches declined with increasing spruce density. Analysis of treatment effects on maximum branch diameter for the whorl close to $1 \mathrm{~m}$ showed a significant interaction between aspen and spruce density. As a result, analysis of aspen density effects was conducted separately for each spruce density (Table 6). With both spruce densities, the maximum branch diameter decreases with increasing aspen density; however, the effects of spruce density were largest in the 0 and 500 aspen ha ${ }^{-1}$ treatment and were not evident for the 4000 aspen $\mathrm{ha}^{-1}$ and unthinned treatments, reflecting differences in spruce crown width across the aspen density gradient. 
Table 5. Effects of treatments on the number and size of branches in the branch whorl closest to $1 \mathrm{~m}$ height. Analysis of treatment effects was based on a factorial design with three levels for aspen density and two levels for spruce density. For both aspen treatment density (AwTDen) and spruce treatment density (SwTDen), means followed by different letters differed significantly $(\alpha=0.05)$ based on Tukey's HSD test.

\begin{tabular}{|c|c|c|c|c|}
\hline & \multicolumn{2}{|c|}{$\begin{array}{l}\text { Average Branch Diameter in } \\
\text { the Whorl Closest to } 1 \mathrm{~m} \text { Height }\end{array}$} & \multicolumn{2}{|c|}{$\begin{array}{l}\text { Number of Live Branches in the } \\
\text { Whorl Closest to } 1 \mathrm{~m} \text { Height }\end{array}$} \\
\hline & $p$ & Means (cm) & $p$ & Means (cm) \\
\hline AwTDen & $<0.0001$ & & ns & \\
\hline SwTDen & ns & & 0.0025 & \\
\hline AwTDen*SwTDen & ns & & ns & \\
\hline AwTDen $=0$ & & $2.2 \mathrm{a}$ & & 2.1 \\
\hline AwTDen = 500 & & $1.5 b$ & & 2.4 \\
\hline AwTDen $=1500$ & & $1.6 \mathrm{~b}$ & & 2.9 \\
\hline AwTDen $=4000$ & & $1.3 \mathrm{bc}$ & & 3.1 \\
\hline AwTDen = unthinned & & $1.0 \mathrm{c}$ & & 2.7 \\
\hline SwTDen $=500$ & & 1.5 & & $3.2 \mathrm{a}$ \\
\hline SwTDen $=1000$ & & 1.4 & & $2.1 b$ \\
\hline
\end{tabular}

Table 6. Effects of treatments on maximum branch diameter in the branch whorl closest to $1 \mathrm{~m}$ of dominant spruce. Analysis for treatment effects was based on a factorial design with three levels for aspen density and two levels for spruce density-since the interaction term was significant, results were analyzed separately for each of the two spruce densities. For aspen treatment density (AwTDen), means followed by different letters (within each spruce density, SWTDen) differed significantly $(\alpha=0.05)$ based on Tukey's HSD test.

\begin{tabular}{|c|c|c|c|c|}
\hline & \multicolumn{4}{|c|}{$\begin{array}{l}\text { Spruce Treatment Density (SwTDen) } \\
\left(\text { (Stems ha }^{-1}\right)\end{array}$} \\
\hline & \multicolumn{2}{|c|}{500} & \multicolumn{2}{|c|}{1000} \\
\hline & $p$ & Means (cm) & $p$ & Means (cm) \\
\hline AwTDen & $<0.0001$ & & 0.0002 & \\
\hline AwTDen = 0 & & $2.9 \mathrm{a}$ & & $2.0 \mathrm{a}$ \\
\hline AwTDen = 500 & & $1.9 \mathrm{~b}$ & & $1.6 \mathrm{abc}$ \\
\hline AwTDen $=1500$ & & $1.9 \mathrm{~b}$ & & $1.7 \mathrm{ab}$ \\
\hline AwTDen = 4000 & & $1.4 \mathrm{bc}$ & & $1.4 \mathrm{bc}$ \\
\hline AwTDen = unthinned & & $1.1 \mathrm{c}$ & & $1.2 \mathrm{c}$ \\
\hline
\end{tabular}

\subsection{Models Describing Variation in Crown Characteristics, Branch Diameter, and Numbers of Branches}

Simple linear regression models were used to examine relationships between tree crown characteristics and stand and tree characteristics. As shown in Table 7, tree height explained $33.8 \%$ of the variation in live crown ratio, $39.6 \%$ of the variation in crown width, and $5.2 \%$ of the variation in height to base of the live crown. Crown width explained $15.1 \%$ of the variation in live crown ratio and was not significant in the model for height to crown base. DBH explained $68.6 \%$ of the variation in crown width, followed by slenderness, which explained $50.4 \%$.

The only significant independent variable describing variation in the number of live branches in the $1 \mathrm{~m}$ whorl was HTLC. However, this linear model explained only $8.5 \%$ of the variation in number of live branches. HTLC ranged from 0.2 to 1.4 , with the number of live branches in the whorl closest to $1 \mathrm{~m}$ declining with increasing HTLC. 
Table 7. Simple linear regression models for estimating crown characteristics for the sampled spruce. Model $Y=a+b x$. $\left(\mathrm{HT}=\right.$ height $(\mathrm{m}) ; \mathrm{HTLC}=$ height to the base of the live crown $(\mathrm{m}) ; \mathrm{Aw} \_\mathrm{sph}=\operatorname{aspen~stems~ha~}^{-1}\left(\mathrm{stems} \mathrm{ha}^{-1}\right) ; \mathrm{DBH}=\mathrm{diameter}$ at breast height $(\mathrm{cm}) ; \mathrm{CW}=$ Crown width $(\mathrm{m}) ; \mathrm{LCR}=$ live crown ratio $(\mathrm{LCR}=(\mathrm{HT}-\mathrm{HTLC}) / \mathrm{HT})$; Slenderness = HT $/ \mathrm{DBH}$; Aw_Baha $=$ aspen basal area ha $\left.{ }^{-1}\left(\mathrm{~m}^{2} \mathrm{ha}^{-1}\right)\right)$. Only significant $(p<0.05)$ models are shown.

\begin{tabular}{|c|c|c|c|c|c|c|c|c|}
\hline $\begin{array}{c}\text { Dependent } \\
\text { Variable }\end{array}$ & $\begin{array}{c}\text { Independent } \\
\text { Variable }\end{array}$ & a (Estimate) & a (SE) & b (Estimate) & b (SE) & $n$ & $R_{\text {adj }}^{2}$ & RMSE \\
\hline \multirow[t]{7}{*}{ LCR } & HT & 0.7464 & 0.0205 & 0.0171 & 0.0028 & 73 & 0.3376 & 0.0396 \\
\hline & HTLC & 0.9646 & 0.0165 & -0.1072 & 0.0177 & 73 & 0.3307 & 0.0398 \\
\hline & Aw_sph & 0.8936 & 0.0078 & -0.0000205 & 0.00005 & 73 & 0.1846 & 0.0439 \\
\hline & DBH & 0.8158 & 0.0143 & 0.0047 & 0.0012 & 73 & 0.1724 & 0.0443 \\
\hline & CW & 0.8007 & 0.0191 & 0.0215 & 0.0058 & 73 & 0.151 & 0.0448 \\
\hline & Slenderness & 0.9183 & 0.0213 & -0.0702 & 0.0293 & 73 & 0.0617 & 0.0471 \\
\hline & Aw_Baha & 0.8872 & 0.0010 & -0.0014 & 0.0006 & 73 & 0.0497 & 0.0474 \\
\hline \multirow[t]{2}{*}{ HTLC } & LCR & 3.6463 & 0.4564 & -3.1710 & 0.5243 & 73 & 0.3307 & 0.2165 \\
\hline & HT & 0.6020 & 0.1335 & 0.0403 & 0.0182 & 73 & 0.0516 & 0.2577 \\
\hline \multirow[t]{6}{*}{$\mathrm{CW}$} & $\mathrm{DBH}$ & 1.2432 & 0.1650 & 0.1720 & 0.0137 & 73 & 0.6863 & 0.5113 \\
\hline & Slenderness & 5.5897 & 2.9011 & -3.4438 & 0.4003 & 73 & 0.5035 & 0.6433 \\
\hline & $\mathrm{HT}$ & 0.6948 & 0.3676 & 0.3469 & 0.0500 & 73 & 0.3957 & 0.7096 \\
\hline & Aw_sph & 3.38352 & 0.1267 & -0.0005502 & 0.00008 & & 0.3913 & 0.7122 \\
\hline & Aw_Baha & 3.9006 & 0.16398 & -0.0558 & 0.0105 & 73 & 0.2726 & 0.7786 \\
\hline & LCR & -3.4009 & 1.7728 & 7.5716 & 2.0366 & 73 & 0.1512 & 0.8410 \\
\hline
\end{tabular}

Tree DBH was a stronger predictor (i.e., it had a larger adjusted coefficient of determination) of branch diameter (DMax2, DMax1, and DMean1) than slenderness (Figure 2, Table 8). Branch diameter was negatively correlated with aspen basal area and the number of aspen per hectare, with aspen basal area ranking in 3rd (DMax2) and 4th (DMax1 and DMean1) place and explaining 60\% (DMax2), 35\% (DMax1) and 42\% (DMean1) of the variation in branch diameter. Crown width ranked in 5th place behind other predictors of branch diameter, while height and live-crown ratio explained less than $25 \%$ of the variation in branch diameter.

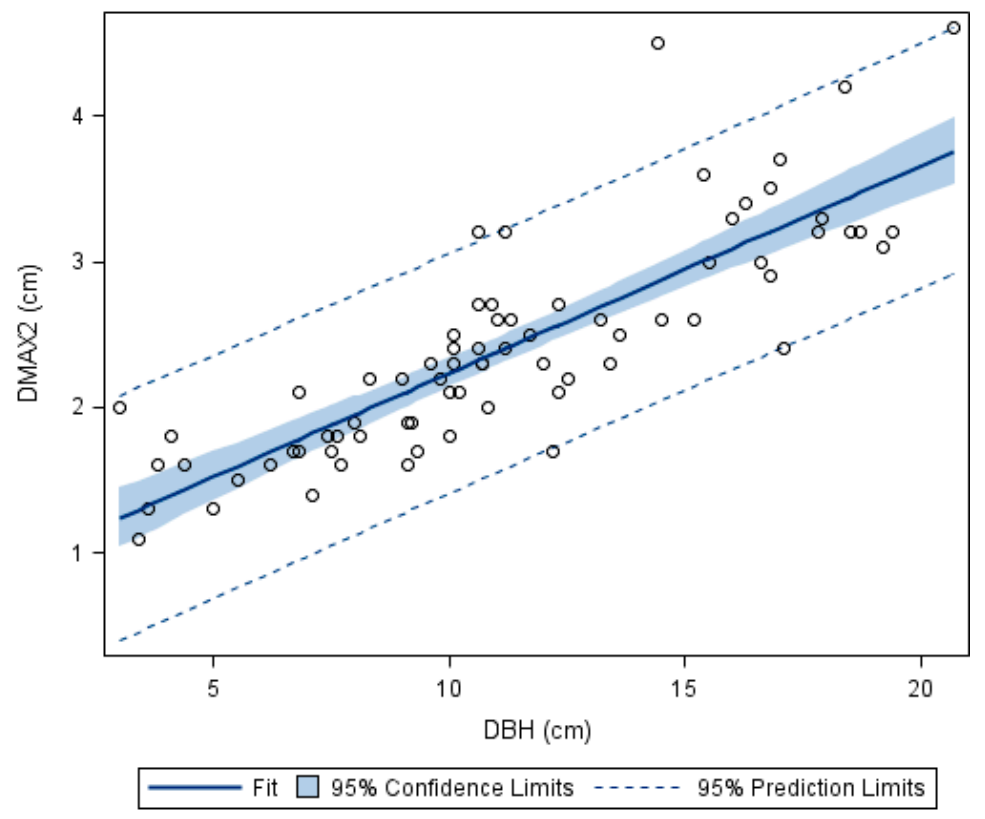

Figure 2. Relationship between maximum branch diameter on the lower $2 \mathrm{~m}$ stem section (DMAX2) and tree DBH. Parameter estimates for the linear model are provided in Table 8. 
Table 8. Linear models describing variation in branch diameter. (DMax2 = maximum branch diameter in the lower $2 \mathrm{~m}$ section of the stem $(\mathrm{cm})$; DMax1 = maximum live branch diameter in the whorl closest to $1 \mathrm{~m}(\mathrm{~cm})$; DMean1 = average live branch diameter in the whorl closest to $1 \mathrm{~m}(\mathrm{~cm}) ; \mathrm{DBH}=$ diameter at breast height $(\mathrm{cm})$; Slenderness $=\mathrm{HT} / \mathrm{DBH}$; Aw_Baha = aspen basal area ha ${ }^{-1}\left(\mathrm{~m}^{2} \mathrm{ha}^{-1}\right) ; \mathrm{Aw} \_\mathrm{sph}=$ aspen stems ha ${ }^{-1}\left(\# \mathrm{ha}^{-1}\right) ; \mathrm{CW}=$ Crown width $(\mathrm{m}) ; \mathrm{HT}=\mathrm{height}(\mathrm{m})$; $\mathrm{LCR}=$ live crown ratio $(\mathrm{LCR}=(\mathrm{HT}-\mathrm{HTLC}) / \mathrm{HT}) ; \mathrm{HTLC}=$ height to the base of the live crown $(\mathrm{m}))$. ns = model not significant ( $\alpha=0.05)$.

\begin{tabular}{|c|c|c|c|c|c|c|c|c|}
\hline $\begin{array}{c}\text { Dependent } \\
\text { Variable }\end{array}$ & $\begin{array}{c}\text { Independent } \\
\text { Variable }\end{array}$ & a (Estimate) & a (SE) & b (Estimate) & b (SE) & $n$ & $R_{\text {adj }}^{2}$ & RMSE \\
\hline \multirow[t]{8}{*}{ DMax2 } & $\mathrm{DBH}$ & 0.8139 & 0.1322 & 0.1423 & 0.0109 & 73 & 0.6998 & 0.4097 \\
\hline & Slenderness & 4.5889 & 0.2097 & -3.1061 & 0.2893 & 73 & 0.6134 & 0.4688 \\
\hline & Aw_Baha & 3.2805 & 0.0994 & -0.0669 & 0.00639 & 73 & 0.6013 & 0.4721 \\
\hline & Aw_sph & 3.0568 & 0.0878 & -0.0005384 & 0.000055 & 73 & 0.5645 & 0.4931 \\
\hline & $\mathrm{CW}$ & 0.6010 & 0.2306 & 0.5706 & 0.0698 & 73 & 0.4780 & 0.5402 \\
\hline & HT & 1.1078 & 0.3560 & 0.1825 & 0.0484 & 73 & 0.1550 & 0.6873 \\
\hline & LCR & -2.4622 & 1.4774 & 5.6119 & 1.6973 & 73 & 0.1212 & 0.7009 \\
\hline & HTLC & & & & & & ns & \\
\hline \multirow[t]{8}{*}{ DMax1 } & $\mathrm{DBH}$ & 0.5945 & 0.1402 & 0.1016 & 0.0119 & 67 & 0.5212 & 0.4221 \\
\hline & Slenderness & 3.3519 & 0.2112 & -2.3169 & 0.2879 & 67 & 0.4914 & 0.4351 \\
\hline & Aw_sph & 2.1936 & 0.0903 & -0.0004 & 0.00005 & 67 & 0.4020 & 0.4669 \\
\hline & Aw_Baha & 2.3055 & 0.1127 & -0.0425 & 0.0071 & 67 & 0.3533 & 0.4855 \\
\hline & CW & 0.4801 & 0.2254 & 0.3938 & 0.0696 & 67 & 0.3198 & 0.5032 \\
\hline & LCR & -3.7680 & 1.1539 & 6.2891 & 1.3234 & 67 & 0.2464 & 0.5296 \\
\hline & HTLC & 2.4374 & 0.2708 & -0.8464 & 0.3029 & 67 & 0.0935 & 0.5808 \\
\hline & HT & & & & & & ns & \\
\hline \multirow[t]{8}{*}{ DMean1 } & $\mathrm{DBH}$ & 0.4968 & 0.1074 & 0.0892 & 0.0091 & 67 & 0.5888 & 0.3235 \\
\hline & Slenderness & 2.8428 & 0.1734 & -1.9292 & 0.2364 & 67 & 0.4984 & 0.3573 \\
\hline & Aw_sph & 1.8974 & 0.0717 & -0.0003184 & 0.00004363 & 67 & 0.4495 & 0.3705 \\
\hline & Aw_Baha & 2.0130 & 0.0879 & -0.0384 & 0.0055 & 67 & 0.4255 & 0.3785 \\
\hline & CW & 0.3947 & 0.1803 & 0.3461 & 0.0557 & 67 & 0.3632 & 0.4026 \\
\hline & LCR & -2.8227 & 0.9707 & 4.9346 & 1.1132 & 67 & 0.2203 & 0.4455 \\
\hline & HT & 0.6722 & 0.2415 & 0.1130 & 0.0331 & 67 & 0.1390 & 0.4681 \\
\hline & HTLC & & & & & & ns & \\
\hline
\end{tabular}

\section{Discussion}

\subsection{Effects of Thinning and Stand Density on Tree and Crown Characteristics}

Pre-commercial thinning of aspen in mixed stands of aspen and white spruce has been shown to increase the diameter, crown width, and live crown ratio and reduce slenderness of the spruce [16,17], as also found in this study. Other studies show similar effects of stand density on crown size of spruce, lodgepole pine, and subalpine fir in western British Columbia [25], black spruce in Ontario [8], Norway spruce in France [21], and Scots pine in Finland [26]. Increasing height and increasing overtopping competition also led to a decrease in live crown ratio for interior spruce in B.C. [14]. Results from this study, showing that crown size declines with increasing competition and increases following thinning, are consistent with the findings of other studies $[7,9,25]$ and support Hypothesis 1 . However, aspen density at age 26 explained only $18.5 \%$ of the variation in spruce live crown ratio and $39.1 \%$ of the variation in spruce crown width in the stands at Big River. Spruce density and basal area were not significantly related to LCR or crown width in this study, reflecting the fact that spruce have only achieved closed canopy conditions in plots with 1000 spruce and 0 or 200 aspen ha ${ }^{-1}$.

\subsection{Effects of Aspen and Spruce Density on Branch Diameter and Number}

Maximum and average branch diameter were affected by aspen density with results supporting Hypothesis 1 . In the case of maximum branch diameter at $1 \mathrm{~m}$ height, spruce density was also significant and interacted with aspen density, with spruce density having stronger impact in the absence of aspen or in the 500 aspen ha $^{-1}$ treatment. This outcome 
reflects increasing delays in crown closure in the spruce layer associated with increasing aspen density. Intraspecific competition and self-shading are likely to have increasing influences on crown rise and the diameter of lower branches as the spruce becomes larger. Spruce density, but not aspen density, influenced the number of live branches in the $1 \mathrm{~m}$ whorl and for the lower $2 \mathrm{~m}$ stem section and number of live branch whorls below $2 \mathrm{~m}$. This is associated with both the moderate shade tolerance of spruce [15] and the fact that intraspecific competition has stronger effects than interspecific competition with aspen. Other studies have reported increases in branch numbers with increasing DBH [2], decreasing slenderness [6] and decreasing stand density [8]. Height increment during the year of branch initiation or the preceding year, distance from top of the tree crown, intra- and inter-specific competition, and competition between branches within the tree are among several factors that appear to influence branch numbers $[2,6,7,27]$.

\subsection{Relationships between Tree Dimensions, Crown Dimensions, and Branch Diameter}

While several studies show that branch diameter, height to base of live crown, and other tree characteristics related to the number and size of knots are related to crown width $[1,14,18,19]$, crown width was not significant as a predictor of height to base of live crown in this study and ranked in 5th place as a predictor of maximum and mean branch diameter. Relationships between branch diameter and slenderness $[1,6,9,20]$ and between branch diameter and tree size (DBH or height) $[2,7,14]$ were also observed in this study and support Hypothesis 2, with diameter being a stronger predictor (larger adjusted coefficient of determination) than slenderness. Crown width ranked in 5th place behind other predictors of branch diameter but was positively correlated with $\mathrm{DBH}$ and slenderness as reported by other studies $[1,14,18,19]$. Tree height and live-crown ratio explained less than $25 \%$ of the variation in spruce branch diameter at Big River. Branch diameter was negatively correlated with aspen basal area and number of aspen per hectare, with these ranking in 3rd and 4th place and explaining between $35 \%$ and $60 \%$ of the variation in branch diameter, similar to results from Groot and Schneider [1].

\subsection{Management Implications}

Results from this study demonstrate the potential to use aspen competition to reduce the sizes of lower stem branches and associated sizes of knots. However, this comes at a cost of reduced diameter growth while providing ecological benefits associated with growing mixed stands that include increased species and structural diversity, improved habitat, nursing effects, and increases in total stand yield. Results also indicate that early thinning to low densities could lead to increases in the size of knots, particularly when spruce densities are low. An alternative approach would be to establish spruce at higher densities, rely on intraspecific competition to more effectively regulate crown length, branch diameter, and branch number, and use timely thinning treatments to manage for a suitable balance of wood properties and stand yields.

\subsection{Study Limitations and Future Needs}

This study is limited by the following: (1) the limited range of spruce planting densities available in this experiment (500 and 1000 stems ha $^{-1}$ ); (2) measurements of branches on only the lower $2 \mathrm{~m}$ of the stem; (3) a lack of temporal data to document crown dynamics; (4) selection of only the largest spruce rather than a range of size classes of spruce; and (5) limited geographic range of study sites. Further studies examining the effects of a wider range of spruce planting densities, in both pure and mixed stands, and including a range of thinning options are needed. Detailed studies of crown profiles and changes over time, involving the measurement and remeasurement of branches along the entire stem (e.g., 4, 5, 6, 7, 18 and 22) would be useful for characterizing, understanding, and modeling crown and branch dynamics in future studies. The use of non-destructive approaches, such as photogrammetric methods [28], would be desirable in these and other permanent sample plots. Since the size of white spruce influences growth rates and competitive 
hierarchy [3] affects the social position of trees, the number and size of branches should be examined based on data for all size classes of trees. A neighborhood study in similar stands in Alberta [3] indicated that distance-independent indices were superior to distancedependent indices for describing variation in stem volume growth, and that basal area was a potentially effective measure of competition. The measurement of competition in individual tree neighborhoods $[7,22]$ together with the testing of both distance-dependent and distance-independent competition indices may provide better models describing the effects of competition on crown and branch dimensions than those based on full treatment plot values due to better representation of the growth environment of each individual tree. Data from additional locations would also provide more broadly applicable understanding and models.

The remeasurement of trees at approximately 10-year intervals (height, DBH, height to base of live crown width, as well as crown profile measurements on a subsample of measured trees) would provide valuable information that could be used in estimating and modeling crown and branch characteristics. The use of remote sensing (using LiDAR and/or high-resolution digital aerial photography) should be explored for measuring crown width, tree height, and stand density $[19,29]$ and for tracking changes in crown and branch characteristics. Over the long term, measurements of knot size and number along the stem should be obtained from a sample of trees in these plots when the spruce are ready for harvest.

\section{Conclusions}

The thinning of aspen has resulted in an increase in spruce branch diameters in this study. Increases in spruce branch diameter were associated with increases in DBH, crown width, and other variables following thinning. Results indicate that early thinning to low aspen densities could lead to increases in the abundance and size of knots and associated reductions in wood quality, particularly when spruce densities are low. The results from this study also indicate that growing spruce in mixture with aspen can lead to reductions in branch and knot size, which may contribute to improvements in wood quality and lumber grade. While these results are consistent with observations at other sites and in the literature, measurements from this stand and other locations, repeated periodically, would provide a basis for the development of general models for describing and predicting branch diameters, branch numbers, and crown recession. Further research is needed to link stand characteristics to knot size and lumber grades in these and other stands.

Author Contributions: Conceptualization, methodology, funding acquisition, data analysis, and writing were completed by P.G.C. All authors have read and agreed to the published version of the manuscript.

Funding: Funding to support the 2018 and 2019 remeasurement and data entry for the Big River LTS installations was provided by the Forest Innovation Program-Canadian Wood Fibre Centre 2018-2019.

Data Availability Statement: The data presented in this study are available on request from the corresponding author.

Acknowledgments: I gratefully acknowledge the involvement of several agencies and individuals in the establishment, management and remeasurement of the Big River WESBOGY Long-Term Study installations. These installations were established by Weyerhaeuser Canada in 1990 and 1992 under the direction of Paul Leblanc and maintained by Weyerhaeuser through 2008. The Canadian Wood Fibre Centre of the CFS accepted responsibility for maintenance and measurement of these installations from 2010 through 2016, and I am grateful to Derrek Sidders, Dan MacIsaac and Tim Keddy for their assistance. I also gratefully acknowledge assistance from Saskatchewan Environment with monitoring and other information relating to these installations and management and provision of previous stand and tree data provided by the WESBOGY project team of the Forest Growth Organization of Western Canada (FGrow). I am particularly grateful to Susah Humphries, Rachel Keglowitsch, Felix Oboite and Kayla Frankiw for their assistance with remeasuring these installations 
and with data entry and preparation and to the Canadian Wood Fibre Centre for funding of this research. I am grateful to two anonymous reviewers who provided valuable suggestions for revisions of this article.

Conflicts of Interest: The authors declare no conflict of interest. The funders had no role in the design of the study; in the collection, analyses, or interpretation of data; in the writing of the manuscript, or in the decision to publish the results.

\section{References}

1. Groot, A.; Schneider, R. Predicting maximum branch diameter from crown dimensions, stand characteristics and tree species. For. Chron. 2011, 87, 542-551. [CrossRef]

2. Auty, D.; Weiskittel, A.R.; Achim, A.; Moore, J.R.; Gardiner, B.A. Influence of early re-spacing on Sitka spruce branch structure. Ann. For. Sci. 2012, 69, 93-104. [CrossRef]

3. Filipescu, C.N.; Comeau, P.G. Aspen competition affects light and white spruce growth across several boreal sites in western Canada. Can. J. For. Res. 2007, 37, 1701-1713. [CrossRef]

4. Deleuze, C.; Hervé, J.C.; Colin, F.; Ribeyrolles, L. Modelling crown shape of Picea abies: Spacing effects. Can. J. For. Res. 1996, 26, 1957-1966. [CrossRef]

5. Achim, A.; Gardiner, B.; Leban, J.M.; Daquitaine, R. Predicting the Branching Properties of Sitka Spruce Grown in Great Britain. N. Z. J. For. Sci. 2006, 36, 246-264. Available online: www.scionresearch.com/_data/assets/pdf_file/0011/59087/06ACHIM.pdf (accessed on 5 December 2020).

6. Hein, S.; Mäkinen, H.; Yue, C.; Kohnle, U. Modelling branch characteristics of Norway spruce from wide spacings in Germany. For. Ecol. Manag. 2007, 242, 155-164. [CrossRef]

7. Weiskittel, A.R.; Maguire, D.; Monserud, R. Modeling crown structural responses to competing vegetation control, thinning, fertilization, and Swiss needle cast in coastal Douglas-fir of the Pacific Northwest, USA. For. Ecol. Manag. 2007, 245, 96-108. [CrossRef]

8. Benjamin, J.G.; Kershaw, J.A.; Weiskittel, A.R.; Chui, Y.H.; Zhang, S.Y. External knot size and frequency in black spruce trees from an initial spacing trial in Thunder Bay, Ontario. For. Chron. 2009, 85, 618-624. [CrossRef]

9. Sattler, D.F.; Comeau, P.G.; Achim, A. Branch models for white spruce (Picea glauca (Moench) Voss) in naturally regenerated stands. For. Ecol. Manag. 2014, 325, 74-89. [CrossRef]

10. Pretzsch, H.; Rais, A. Wood quality in complex forests versus even-aged monocultures: Review and perspectives. Wood Sci. Technol. 2016, 50, 845-880. [CrossRef]

11. Hasenauer, H.; Monserud, R.A. A crown ratio model for Austrian forests. For. Ecol. Manag. 1996, 84, 49-60. [CrossRef]

12. Makela, A.; Vanninen, P. Impacts of size and competition on tree form and distribution of aboveground biomass in Scots pine. Can. J. For. Res. 1998, 28, 216-227. [CrossRef]

13. Ilomaki, S.; Nikinmaa, E.; Makela, A. Crown rise due to competition drives biomass allocation in silver birch. Can. J. For. Res. 2003, 33, 2395-2404. [CrossRef]

14. Temesgen, H.; LeMay, V.; Mitchell, S.J. Tree crown ratio models for multi-species and multi-layered stands of southeastern British Columbia. For. Chron. 2005, 81, 133-141. [CrossRef]

15. Pretzsch, $\mathrm{H}$. The effect of tree crown allometry on community dynamics in mixed-species stands vs monocultures. A review and perspectives for modeling and silvicultural regulation. Forests 2019, 10, 810. [CrossRef]

16. Bokalo, M.; Comeau, P.G.; Titus, S.J. Early development of tended mixtures of aspen and spruce in western Canadian boreal forests. For. Ecol. Manag. 2007, 242, 175-184. [CrossRef]

17. Kabzems, R.; Bokalo, M.; Comeau, P.G.; MacIsaac, D.A. Managed mixtures of aspen and white spruce 21 to 25 years after establishment. Forests 2016, 7, 5. [CrossRef]

18. Garber, S.M.; Maguire, D.A. Vertical trends in maximum branch diameter in two mixed-species spacing trials in the central Oregon Cascades. Can. J. For. Res. 2005, 35, 295-307. [CrossRef]

19. Groot, A.; Cortini, F.; Wulder, M.A. Crown-fibre attribute relationships for enhanced forest inventory: Progress and prospects. For. Chron. 2015, 9, 266-279. [CrossRef]

20. Wang, Y.; Titus, S.J.; LeMay, V.M. Relationships between tree slenderness coefficients and tree or stand characteristics for major species in boreal mixedwood forests. Can. J. For. Res. 1998, 28, 1171-1183. [CrossRef]

21. Colin, F.; Houllier, F. Branchiness of Norway spruce in northeastern France: Predicting the main crown characteristics from usual tree measurements. Ann. Sci. For. 1992, 49, 511-538. [CrossRef]

22. Maguire, D.A.; Moeur, M.; Bennett, W.S. Models for describing basal diameter and vertical distribution of primary branches in young Douglas-fir. For. Ecol. Manag. 1994, 63, 23-55. [CrossRef]

23. Anonymous. Influence of Growth Rate on Strength and Related Wood Properties of Boreal White Spruce; Technote 00-08W; Forintek Canada: Vancouver, BC, Canada, 2000.

24. Soil Classification Working Group. The Canadian System of Soil Classification; Agriculture and Agri-Food Canada Publ.: Ottawa, ON, Canada, 1998; p. 187. Available online: https://sis.agr.gc.ca/cansis/taxa/cssc3/ (accessed on 2 December 2020).

25. Thorpe, H.C.; Astrup, R.; Trowbridge, A.; Coates, K.D. Competition and tree crowns: A neighbourhood analysis of three boreal tree species. For. Ecol. Manag. 2010, 259, 1586-1596. [CrossRef] 
26. Hynynen, J. Predicting tree crown ratio for unthinned and thinned Scots pine stands. Can. J. For. Res. 1995, 25, 57-62. [CrossRef]

27. Makinen, H.; Colin, F. Predicting the number, death and self-pruning of branches in Scots pine. Can. J. For. Res. 1999, 29, 1225-1236. [CrossRef]

28. Grace, J.C.; Brownie, R.K.; Kennedy, S.G. The influence of initial and post-thinning stand density on Douglas-fir branch diameter at two sites in New Zealand. N. Z. J. For. Sci. 2015, 45, 14. [CrossRef]

29. Filipescu, C.N.; Groot, A.; MacIsaac, D.A.; Cruikshank, M.G.; Stewart, J.D. Prediction of diameter using height and crown attributes: A case study. West. J. Appl. For. 2012, 27, 30-35. [CrossRef] 